\title{
変形性膝関節症外来患者の片脚立位における \\ HAT 運動戦略と骨盤周囲筋の関係 \\ Relationship between single leg standing of HAT movement strategy and the surrounding muscles of the pelvis in outpatients with knee osteoarthritis
}

\author{
吉永 龍史
}

RYUji YoshinAGA

\begin{abstract}
要旨：本研究は変形性膝関節症（膝 OA）患者の運動機能改善の指標を明らかにするため に，骨盤運動戦略抢よび Head・Arm・Trunk (HAT) 運動戦略と骨盤周囲筋力の関係を検 討した。対象は, 膝 OA 外来患者14名で，11名は両肢を 3 名は片肢を評価した。方法は, 片脚立位動作を前額面上の写真から肩峰，体幹傾斜抢よび股関節内転角度で骨盤運動と HAT 運動戦略に分類し，中殿筋，大殿筋㧍よび股関節内転筋の最大等尺性収縮を比較し た。その結果, HAT 運動戦略は, 立脚肢の中殿筋の筋力が有意に低下していること, 体 幹㧍よび肩峰傾斜角度と中殿筋の間に負の相関を認めた。歩容で HAT 運動戦略がみられ た場合は，片脚立位の評価を加えることで，中殿筋の弱化傾向を推測できる可能性がある。

キーワード：変形性膝関節症，片脚立位，骨盤周囲筋
\end{abstract}

\begin{abstract}
This study was undertaken to clarify the relationship between pelvis movement strategy, head-arm-trunk (HAT) movement strategy, and the strength of pelvic surrounding muscles in patients with knee osteoarthritis $(\mathrm{OA})$. The subjects were 14 outpatients with knee OA, 11 of whom were evaluated both limbs and 3 were evaluated unilateral limb. We classified the pelvis movement and HAT movement strategy from a photograph of single leg standing on the frontal plane which inclined an angle of the acromion, trunk and adduction of the hip joint. We compared the maximum isometric contraction of gluteus medius muscle, gluteus maximus muscle and adductor muscle about the difference between the pelvis movement and HAT movement strategy. As the results, we found out two important clinical aspects. First, the muscle strength of gluteus medius muscle of HAT movement strategy was significant decreased. Second, the gluteus medius muscle strength and the inclined angle between the acromion and trunk were negatively correlated with HAT movement strategy. The present study suggests that we may estimate the weakening trend of gluteus medius muscle from the single leg standing when we observe HAT movement strategy in knee OA.
\end{abstract}

Key words: knee osteoarthritis, single leg standing, the surrounding muscles of the pelvis

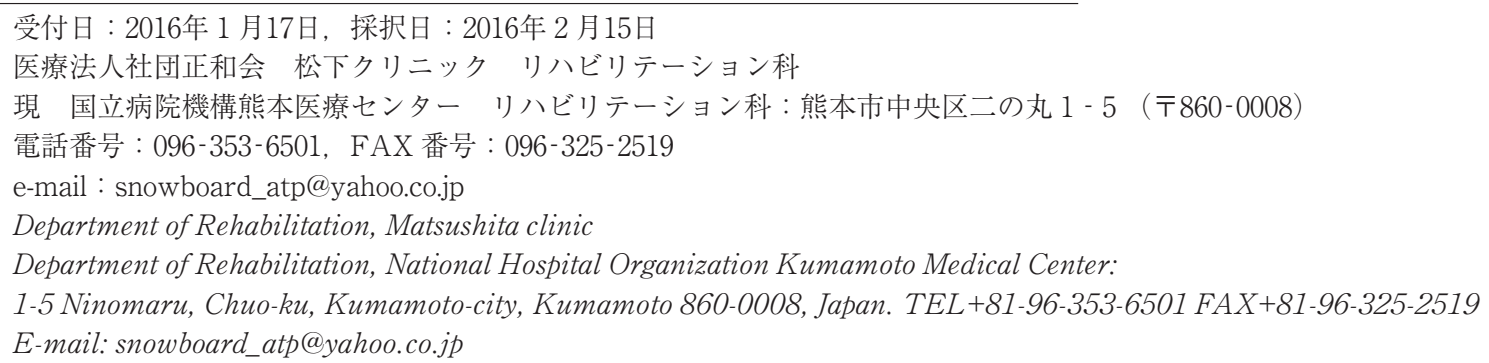




\section{I 、はじめに}

内側型変形性膝関節症（以下, 膝 OA）は, 関節軟 骨の退行性変化を基盤として, 疼痛や関節可動域制限 などの関節機能の障害を来す疾患である11。膝 OAの 我が国の有症状者は 820 万人, 40歳以上の X 線所見で 診断される有病者数は, 2530 万人（男性 860 万人，女 性1670万人）と推定されている2)。膝 OA の発症と関 係のある既往歴は, 前十字勒带損傷および再建術, 半 月板損傷および切除術である3”。また, 危険因子は, 男性と女性で性差はなく, 肥満, 膝の外傷, 肉体労働 である ${ }^{4,5)}$ 。本邦の膝 OA の多くが内側型膝 OA であ り, 病態の進行に伴い $\mathrm{O}$ 脚変形が進行していく ${ }^{6)}$ 。膝 $\mathrm{OA}$ の歩行の 1 つの特徴として, 荷重応答期から立脚 中期にかけて lateral thrust が生じ，これが外部膝関 節内反モーメントを増加させている7)。先行研究では, 外部膝関節内反モーメントが膝 OA の進行に影響す る8) と言われている。

木藤ら ${ }^{9}$ は, 膝 OA を「身体の合理的な関節運動連 鎖と筋活動が障害されることにより，膝関節が有する 機能解剖と運動の合理性から逸脱し, 膝関節内に異常 な圧縮・回旋ストレスが作用した結果生じる膝の症状 を主症状とする運動連鎖機能不全の一病態」と捉えて いる。つまり, 膝 OAに対する理学療法は, 立位や 歩行といった重力環境下で行われる身体活動時の膝に 生じる異常な力学的ストレスを減じる姿勢動作戦略の 獲得が必要であることを意味する。膝 OA 患者は, 前額面の姿勢安定に関わる体幹が加齢に伴い骨盤運動 様式から頭部 ·上肢 - 体幹 (以下, HAT: head, arm, trunk）と下腿傾斜を利用した動作様式へ変化する ${ }^{10)}$ 。 これをHAT 運動戦略と呼ぶ。例えば右の単脚支持期 の時，骨盤運動戦略が右股関節内転による足圧中心を 制御しながら，頭部と体幹は水平位で骨盤移動を行う のに対して, HAT 運動戦略は, HAT と下腿の動き で身体重心と足圧中心の位置を調整し, 右股関節が外 転位となり, 頭部と体幹を右へ傾けて行う動作様式で ある ${ }^{11}$ 。このように膝 OA では，立脚初期に股関節内 転・内旋が不足しているため, 相対的に筋長が短縮す ることで大殿筋や中殿筋による内部股関節外転モーメ ントが発揮しにくく，それに関与する股関節内転筋の 筋力などの骨盤周囲筋の機能低下が HAT 運動戦略の 生じる原因の一つである ${ }^{12)}$ と言われている。歩行時の 前額面上の動作観察として, 片脚立位が歩行時の立脚

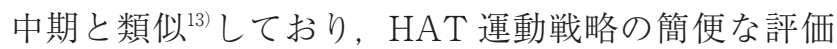
で用いられることがある。よって, 膝 OA の特徵的
な HAT 運動戦略を片脚立位から評価し，大殿筋，中 殿筋および股関節内転筋である骨盤周囲筋の関係を明 らかに出来れば，筋機能低下を推察する 1 つの評価指 標にできると考えられる。また，片脚立位における動 作戦略と骨盤周囲筋の筋力との関係性について明らか にした先行研究はこれまでにない。

本研究の目的は, 膝 OA 患者の片脚立位動作から 評価した骨盤運動戦略と HAT 運動戦略の違いを骨盤 周囲筋の関係から検討した。

\section{II. 対象と方法}

\section{1. 対 象}

被検者は，片側性または両側性内側型膝 OA と診 断された14名で, 女性が13名, 男性が 1 名のうち, 両 側性膝 OA と片側性膝 OA の計25肢とした。膝 OA の内訳は, 片側性膝 OA が 3 名, 両側性膝 OA が11 名だった。基本属性は, 年齢が79.0 $0 \pm 7.4$ 歳, 身長が

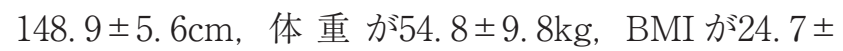
$3.7 \mathrm{~kg} / \mathrm{cm}^{2}$ ，X線画像である Kellgren \& Lawrence 分 類（以下, K-L 分類） II が17肢， III 6 肢，IVが 2 肢 であった。すべての測定は、リハビリテーション室内 のプラットホームで実施した。包含基準は整形外科医 から膝 OA と診断された外来患者であること, 除外 基準は認知症などコミュニケーションに問題ある患者 とした。中止基準は, 本測定を施行中に膝などの疼痛 が増悪した患者とした。なお，本研究は全被験者に研 究の目的と内容を十分に説明し, 文書による同意を得 た上で実施した。

\section{2. 方 法}

運動力学的デー夕は, 骨盤周囲筋である中殿筋, 大 殿筋, 内転筋の最大等尺性収縮時に発揮される力 $(\mathrm{N})$ と大転子から Hand Held Dynamometer (以下, HHD) のセンサーパッド接触部位の中心部までのモーメント アーム $(\mathrm{m})$ を乗し，体重で除した関節モーメントを 筋力值 $(\mathrm{Nm} / \mathrm{kg})$ とした。測定器具は, MICRO FET 2（日本メディクス社製，FET-102）であった。以 下に述べる方法は，すべて筆者が徒手的に 3 回実施し， その 3 回の平均値を代表値とした。測定は, 十分な練 習を実施した後に行った。中殿筋の測定は, ベッド上 に患側上の側臥位となり股関節を外転した肢位を保持 してもらい，股関節が外旋するといった代償動作に留 意しながら大腿遠位外側部を接触した。大殿筋の測定 は，腹臥位で膝は90度屈曲位に保った肢位から股関節 
を伸展してもらい，大腿遠位後面を HHD で圧迫した。 内転筋の測定は, 患側下の側臥位で健側の下肢を股関 節屈曲内転，膝屈曲位でベッド上に設置してから患側 を膝伸展位で保持したまま股関節を内転してもらい, 大腿遠位内側面にHHD を当てた。なお，大殿筋と内 転筋のモーメントアームの計測は, HHD の接触部位 がそれぞれ大腿遠位後面と内側面となるが，大転子か ら大腿骨外側上顆の直線上の距離とするため, 接触部 位から大腿骨長軸の直角に投影した位置を目安とした。 運動学的デー夕は, 被験者の前額面の片脚立位を脚 立に固定したデジタルカメラで撮影した。撮影条件は, 被検者とデジタルカメラの距離が常に一定になるよう に床のテープを目印に脚立の位置を固定し，被写体が フレーム内に全身写るように配慮した。片脚立位の撮 影は，「片脚立位となった直後から 2 秒以上四肢や頭 部の大きな摇れを伴わずに片脚立位保持可能になった 時点」と設定した ${ }^{14)}$ 。被験者の身体上の直径 $20 \mathrm{~mm} の$ 蛍光マーカー貼付部位は, 前頭部, 左右肩峰, 左右上 前腸骨棘，左右膝蓋骨中央の計 7 点とした。また，撮 影したカメラが傾斜している可能性があるため，鉛直 成分はメジャーの巻尺の先端を画鋲で室内の壁に固定 し，本体部分を下垂させた直線上にマーカーを 2 点貼

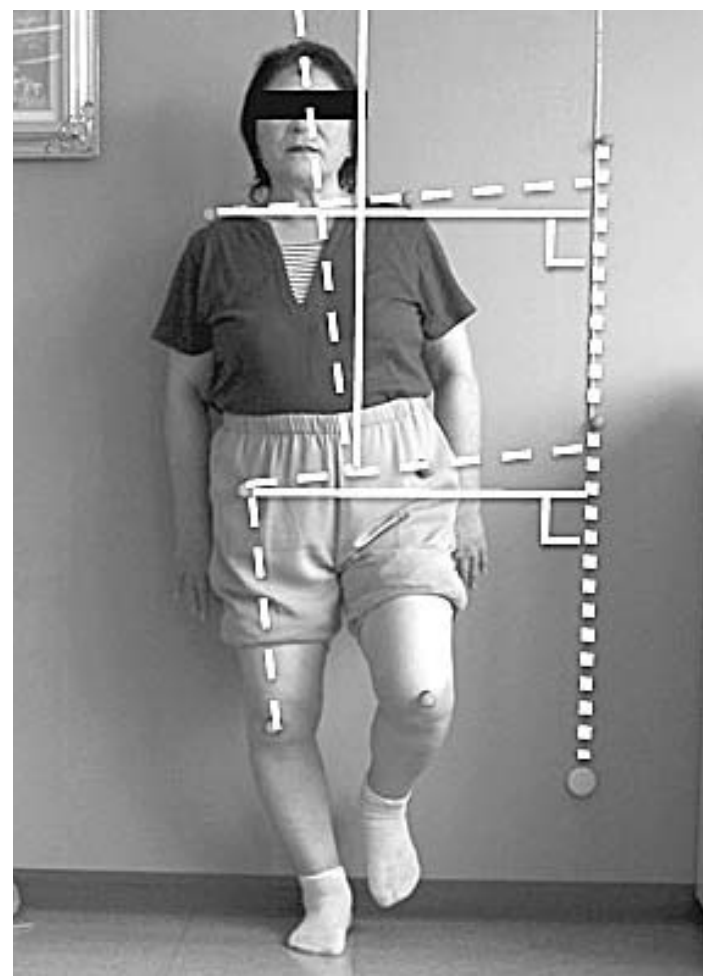

図 1 片脚立位の姿勢分析方法 点線が鉛直成分, 実線が基本軸, 破線が移動軸を 表す。(股関節内転角度の測定時は, 左右上前腸骨 棘が基本軸となる)
付した直線とした。撮影した片脚立位の写真は，パソ コン上に取り込み，画像解析ソフトウェアScion image を用いて以下の 4 点について角度を測定した。体 幹傾斜角度は基本軸が鉛直成分，移動軸が左右上前腸 骨棘の中点と前頭部を結ぶ線, 肩峰傾斜角度は基本軸 が水平面，移動軸が左右肩峰を結ぶ線，骨盤傾斜角度 は基本軸が水平面，移動軸が左右上前腸骨棘を結ぶ線， 股関節内転角度は基本軸が左右上前腸骨棘，移動軸が 膝蓋骨中央を結ぶ線から90度を引いた值とした(図 1)。 画像解析上で測定したそれぞれの角度は，3 回の平均 值を用いた。そして, 膝 OAの25肢は, 立脚側へ体 幹および肩峰傾斜角度の両者が 5 度以上，股関節内転 角度が 5 度未満のすべてを満たすものを HAT 運動戦 略群，それ以外を骨盤運動戦略群と定義し 2 群に分類 した（図 2 )。理由として, HAT 運動戦略とは, 前 述したように膝 OAにおいて股関節の外転と下腿内 反，HAT の動作を組み合わせ，足圧中心と身体重心 の調節を行い，頭部と体幹が傾く動作様式である ${ }^{11}$ と 報告されている。このため, 骨盤の傾きについては言 及されていないことから，上記の 3 つの指標から分類 した。

統計処理は，まず全ての各データを Shapiro-Wilk

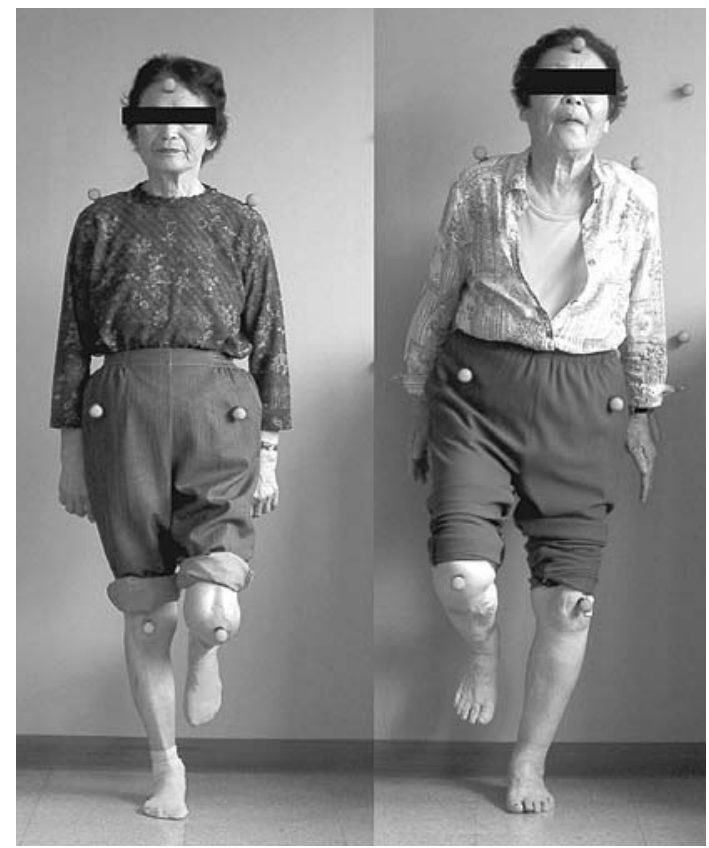

図 2 骨盤運動戦略と HAT 運動戦略 左図は骨盤運動戦略の症例で体幹・肩峰・骨盤が 水平で右股関節が内転位に位置している。一方，右 図は HAT 運動戦略で体幹・骨盤・肩峰が立脚側へ 傾き，左股関節が下腿傾斜も加わり内転位に位置で きていない。 
検定で正規性の有無を確認した。HAT 運動戦略群と 骨盤運動戦略群の 2 群について K-L 分類に比率の差 がないかを Fisherの正確確率検定，骨盤周囲筋筋力 值の差を明らかにするために中殿筋，大殿筋および内 転筋それぞれについて平均值の比較の場合は対応のな い $\mathrm{t}$ 検定, 中央值の比較は Mann-Whitney の U 検定 を選択した。次に，2 群間の片脚立位動作時の体幹, 肩峰，骨盤傾斜角度および股関節内転角度と骨盤周囲 筋筋力值の関連性を明らかにするために，平均值の比 較はPearsonの相関分析, 中央值の比較は Spearman の順位相関係数をそれぞれ使用した。なお，有意水準 は両側 $5 \%$ 未満とした。すべての統計解析は, R2.8.1 （CRAN， free software）を使用した。

\section{III. 結 果}

Shapiro-Wilk 検定より正規性に従う場合は平均值士 標準偏差, 正規性に従わない場合は中央值（範囲）で 表記した。骨盤運動戦略群は12肢, HAT 運動戦略群 は13肢であった。表 1 に, 骨盤運動戦略群と HAT 運 動戦略群の 2 群間における部位別傾斜角度と筋力值の
比較を示す。統計解析の結果, 2 群間の K-L 分類の 比率の差については, 有意差を認めなかった。2 群間 の筋力值の差の比較は, 大殿筋 $(\mathrm{p}=0.07)$ と内転筋 （ $\mathrm{p}=0.07 ）$ に有意差を認めなかったが，中殿筋（p $<0.05 ） の み \mathrm{HAT}$ 運動戦略群が骨盤運動戦略群と比 べ有意に筋力が低下していた。

表 2 に, 骨盤運動戦略群と HAT 運動戦略群それぞ れの片脚立位動作時の体幹, 肩峰傾斜角度および股関 節内転角度と骨盤周囲筋筋力值の関連性を示す。骨盤 運動戦略群は，すべて有意な相関を認めなかったのに 対し, HAT 運動戦略群が肩峰傾斜角度および中殿筋 の間（ $\mathrm{p}<0.05, r=-0.62)$, 体幹傾斜角度および中 殿筋の間 $(\mathrm{p}<0.05, \quad \mathrm{r}=-0.68)$ の両者に有意な負の 相関を認めた。

\section{IV. 考 察}

本研究結果より, 以下 2 点が示された。第 1 に, 膝 $\mathrm{OA}$ 患者の片脚立位評価でみられる HAT 運動戦略は 立脚肢の中殿筋の筋力低下が関係していた。第 2 に, HAT 運動戦略の片脚立位評価時の体幹あるいは肩峰

表 1 部位別の傾斜角度と筋力値の 2 群間の比較

\begin{tabular}{|c|c|c|c|}
\hline & 骨盤運動戦略群 (n=12) & HAT 運動戦略群 $(\mathrm{n}=13)$ & $\mathrm{p}$ 值 \\
\hline K-L 分類 (II /III / IV)（肢) & $9 / 3 / 0$ & $8 / 3 / 2$ & 0.56 \\
\hline 肩峰傾斜角度（ ${ }^{\circ}$ ) & $0.2 \pm 3.7$ & $8.1(5.5-17.8)$ & $<0.001$ \\
\hline 体幹傾斜角度（０） & $2.5 \pm 4.5$ & $7.6(5.0-15.8)$ & $<0.001$ \\
\hline 骨盤傾斜角度（ํ) & $2.8 \pm 4.5$ & $7.2(5.0-13.9)$ & $<0.001$ \\
\hline 股関節内転角度（ํ) & $8.5 \pm 3.9$ & $0.3(-4.3-4.0)$ & $<0.001$ \\
\hline 大殿筋 $(\mathrm{Nm} / \mathrm{kg})$ & $0.44 \pm 0.18$ & $0.32 \pm 0.15$ & 0.07 \\
\hline 中殿筋（Nm/kg） & $0.84(0.47-1.57)$ & $0.60 \pm 0.26$ & $<0.05$ \\
\hline 内転筋 $(\mathrm{Nm} / \mathrm{kg})$ & $0.48 \pm 0.18$ & $0.36 \pm 0.14$ & 0.07 \\
\hline
\end{tabular}

平均值土標準偏差

中央値（範囲）

K-L : Kellgren \& Lawrence

表 2 片脚立位動作時の傾斜角度と筋力值の相関係数

\begin{tabular}{lrrr}
\hline & 大殿筋 & 中殿筋 & 内転筋 \\
\hline (a) 骨盤運動戦略群 $(\mathrm{n}=12)$ & & & \\
肩峰傾斜角 & 0.28 & 0.31 & 0.20 \\
骨盤傾斜角 & 0.13 & 0.17 & 0.13 \\
体幹傾斜角 & 0.02 & 0.10 & -0.13 \\
股関節内転角度 & -0.16 & 0.15 & -0.52 \\
(b) HAT 運動戦略群 $(\mathrm{n}=13)$ & & & \\
肩峰傾斜角 & -0.19 & $-0.62^{*}$ & -0.23 \\
骨盤傾斜角 & 0.12 & -0.43 & 0.36 \\
体幹傾斜角 & -0.32 & $-0.68^{*}$ & -0.13 \\
股関節内転角度 & 0.49 & 0.10 & 0.49 \\
\hline
\end{tabular}

${ }^{*} \mathrm{p}<0.05$ 
傾斜角度が立脚側へ増加すればするほど中殿筋の筋力 がより低下している可能性があるという負の相関が認 められた。

膝 OA 患者の片脚立位評価でみられる HAT 運動戦 略は, 立脚肢の中殿筋の筋力低下が関係していた。木 藤ら ${ }^{15)}$ によると, 膝 OA の立脚初期に大殿筋や中殿筋 といった内部股関節外転モーメントを発揮するために は，立脚初期の股関節内転・内旋運動が起こることが 重要である。さらに, 荷重応答期から初期立脚中期ま でに股関節内転・内旋運動が起こらなければ，単脚支 持期に外部膝関節内反モーメントが増加すると述べて いる。本研究結果から, 片脚立位の前額面の評価より, 骨盤運動戦略群と比較して HAT 運動戦略群は, 股関 節内転角度が有意に減少，体幹，肩峰掞よび骨盤傾斜 角度がすべて立脚側へ有意に増加していた。片脚立位 は，バランス評価や姿勢観察などで理学療法士がよく 使用する簡易的な評価である。今回, 前額面の片脚立 位姿勢を画像上から客観的に体幹・肩峰 - 骨盤・股関 節内転角度の 4 点を同時に評価し, 筋力との関係を検 討したことは非常に臨床的で新規性がある。片脚立位 動作は，前述したように立脚中期の評価に近い ${ }^{13}$ 。健 常者と膝 OA を比較した木藤らの先行研究》によると, 片脚起立期の外部膝関節内反モーメントの比率の増加 は，前額面の身体バランス制御において股関節の役割 が減少し, 膝関節の内側コンパートメントに生じる圧 縮ストレスなどが増えていることを意味している。骨 盤運動戦略群と比べ HAT 運動戦略群は, 股関節内転 可動域が減少していたことから，本研究のように膝 $\mathrm{OA}$ の中でも片脚立位時の股関節の位置関係を含めた 前額面上の姿勢制御について評価していくことが重要 であることがわかる。また，今回興味深いことに，骨 盤運動戦略群と比べ HAT 運動戦略群は, 骨盤傾斜角 度が最低でも 5 度以上立脚側に有意に増加していた。 このことは, HAT 運動戦略の片脚立位での動作では, デュシェンヌ歩行のように股関節内転不足に加え, 骨 盤傾斜角度もさらに増加するという動作確認も重要で あることを意味している。木藤が述べているように， 荷重応答期から立脚中期に内部股関節外転モーメント を発揮するためには，股関節を内転位に位置させ，特 に中殿筋の筋機能を高めることが理学療法戦略に必須 である。以上より, 膝 OA の肩峰, 体幹, 骨盤傾斜 が立脚側へ増加揖よび股関節内転不足の片脚立位動作 は, 特に中殿筋の最大等尺性筋力低下と関係する 1 つ の観察評価になる可能性がある。
HAT 運動戦略は, 片脚立位評価時の体幹あるいは 肩峰傾斜角度が立脚側へ増加すればするほど中殿筋の 筋力がより低下している可能性があるという負の相関 が認められた。先行研究によると, 膝 OAの立脚側 への肩峰掞よび体幹傾斜は, 外部膝関節内反モーメン 卜を減少させる補償戦略であると言われている16,17)。 本研究結果は, HAT 運動戦略群のみ肩峰扮よび体幹 傾斜角度と中殿筋の間に有意な負の相関を示した。片 脚立位の前額面上の姿勢の安定は, Pauwels の理論 ${ }^{18)}$ と呼ばれる天秤の棒で考えることができる。片脚立位 の安定は，股関節の骨頭中心を支点にすると，中殿筋， 大腿筋膜張筋㧍よび大殿筋といった内部股関節外転 モーメントと体重による外部股関節内転モーメントが 等しくならなければ骨盤が側方へ傾くことになる。骨 盤運動戦略は，体幹を立脚側に傾けなくても内部股関 節外転モーメントが十分であるため前額面上の姿勢を 安定させることができるのに対し，HAT 運動戦略は， 上半身重心の体重を立脚側の支点である大腿骨頭中心 に近づけ，モーメントアームを短くすることで中殿筋 などの内部股関節外転モーメントを減少させていたと 考えられる。さらに, 股関節を内転位に保てない HAT 運動戦略は，中殿筋などの筋の起始と停止が近づくた め内部股関節外転モーメントが発揮しにくい身体環境 となっている。これらのことから, HAT 運動戦略は, 肩峰および体幹傾斜を立脚側に傾ける角度が増加して いるほど，中殿筋と負の相関が認められたと考えられ る。以上より, HAT 運動戦略の片脚立位動作は, 肩 峰と体幹傾斜角度が立脚側へ傾けば傾くほど，中殿筋 の筋力低下がより強いという関連性を示す 1 つの徴候 であると考えられる。

本研究の片脚立位評価の方法は, 臨床的に大変安易 でかつ経済的である。今回, 本研究の結果を臨床で用 いるとすれば, 保存療法で膝 OA 患者の理学療法を 担当した時, 歩容で HAT 運動戦略が見られれば, 片 脚立位を行い肩峰・体幹が立脚側へ傾き, かつ遊脚側 の骨盤が拳上，さらには股関節が内転位に位置できて いなければ中殿筋の弱化傾向を反映する1つの徵候と なる。加え, 肩峰と体幹が立脚側への傾きが強ければ 強いほど，中殿筋の筋力はより低下しているかもしれ ないということになる。

本研究には 3 つの限界がある。第 1 は対象者の数が 少なかったことである。木藤らによると, 膝 OA の 股関節周囲筋である大殿筋，内転筋抒よび膝伸展筋は 有意に筋力低下が認められた ${ }^{19)}$ と報告している。今後 
は，対象者を増加するとともに，体幹，膝あるいは足 関節周囲筋など評価項目を増やして検討する必要があ る。第 2 は，筋力測定の信頼性がそしいことである。 HHD の測定は，徒手的に行うよりもべルトで固定し た方法の方が信頼性が高いことが示されている20)。今 後は，ベルトを用いた信頼性の高い方法で筋力測定を 行う必要がある。第 3 は, 本研究が横断研究であるた め, 中殿筋の筋力低下が HAT 運動戦略を引き起こし た原因なのか，あるいはその結果なのかについての因 果関係を導くことが難しい。これを明らかにするため には, 縦断研究で要因と時間的な関係性について今後 検証しなければいけない。

本研究では, 外来の膝 OA 患者において, 片脚立 位評価でみられる HAT 運動戦略は, 立脚肢の中殿筋 の筋力低下が関係していること, 体幹あるいは肩峰傾 斜角度が立脚側へ増加すればするほど中殿筋の筋力が より低下している可能性があるという負の相関が認め られたこと，がわかった。今回対象者は限定されてい るが, 歩容で HAT 運動戦略がみられた場合は, 片脚 立位の評価を加えることで，中殿筋の弱化傾向を推測 できる可能性がある。今後, 本研究のような横断研究 により, 歩行の動作分析は, 臨床経験に関わらず跛行 の問題を立脚期のどの期に問題があるのかといった簡 易的に絞り込むような評価のアルゴリズムの構築が必 要である。

本研究の一部は，2010年12月に開催された第15回広 島県理学療法学会（三原市）で発表したものである。

\section{引用文献}

1) 齋藤知行, 腰野富久, 竹内良平: 変形性膝関節症に抢ける 軟骨修復。関節外科，2006，25（suppl-1）：92-98.

2) 吉村典子：本邦における変形性関節症の現状. Anti-aging Science, 2015, 7 (2) : 88-91.

3 ) Oiestad BE, Engebretsen L, Storheim K, et al. : Knee osteoarthritis after anterior cruciate ligament injury: a systematic review. Am J Sports Med, 2009, 37(7): 1434-1443.

4) Yoshimura N, Kinoshita H, Hori N, et al. : Risk factors for knee osteoarthritis in Japanese men: a case-control study. Mod Rheumatol, 2006, 16(1): 24-29.

5 ) Yoshimura N, Nishioka S, Kinoshita H, et al. : Risk factors for knee osteoarthritis in Japanese women: heavy weight, previous joint injuries, and occupational activities. J Rheumatol, 2004, 31(1): 157-162.

6）腰野富久：スポーツと変形性膝関節症㧍よびその手術。日 臨スポーツ医会誌，2006，14(2)：143-155.

7 ）木藤伸宏，新小田幸一, 金村尚彦·他：内側型変形性膝関
節症の外部膝関節内反モーメントと疼痛，身体機能との関 係. 理学療法科学, 2008, 23(5)：633-640.

8 ）古賀 寛, 大森 豪：滕関節の運動機能診断の基礎一変形 性膝関節症に打ける運動機能一, 関節外科, 2014，33 (10) : 1069-1072.

9 ）木藤伸宏, 石井慎一郎, 三輪 恵：変形性膝関節症の理学 療法の加速的アプローチ．理学療法，2003，20(4)：429438.

10）木藤伸宏：変形性膝関節症に対する理学療法戦略．香川県 理学療法士会学会誌, 2010, (16)：10-17.

11）菅川祥枝, 木藤伸宏：変形性滕関節症患者の生活機能卜 レーニングの考方方とその実際. 理学療法, 2007，24(4)： 565-572

12）木藤伸宏，山崎貴博，岡西奈津子 -他：変形性膝関節症の 理学療法における運動制御・学習理論の応用. 理学療 法, 2009, 26(7)：849-862.

13）阿南雅也，徳田一貫，木藤伸宏・他：膝関節疾患による異 常歩行とその分析. 理学療法, 2009, 26(1) : 138-147.

14）杉本寿司，佐藤明紀，山本祥子・他：体幹深部筋に対する エクササイズが片脚立位に及ほす影響。北海道理学療 法, 2010, $27: 35-38$.

15）木藤伸宏：内側型変形性膝関節症に対する理学療法. 理学 療法兵庫，2009, (15)：25-30.

16）徳田一貫, 新小田幸一, 羽田清貴 -他：内側型変形性膝関 節症に抢ける歩行立脚時の関節角度と大腿・下腿回旋運動 の評価. 理学療法科学, 2014, 29(3)：437-442.

17) Hunt MA, Birmingham TB, Bryant D, et al. : Lateral trunk lean explains variation in dynamic knee joint load in patients with medial compartment knee osteoarthritis. Osteoarthritis Cartilage, 2008, 16(5): 591-599.

18） J.Castaing, J. Delplace : 図解関節・運動器の機能解剖下肢 編。井原秀俊，中山彰一，井原和彦共訳，協同医書出版社， 東京, 2005，49-53.

19）木藤伸宏：変形性膝関節症に対する理学療法. 理学療法京 都，2010，(39）：49-53

20）山崎裕司，片岡千春，大倉三洋・他：ハンドヘルドダイナ モメーターによる等尺性股関節外転筋力の測定一固定用べ ルトの使用が再現性に与える影響一. 高知リ八学院 紀, 2008, 10：61-66. 